\title{
O konieczności utrzymania habilitacji w Polsce
}

\author{
Jerzy Marian Brzeziński
}

\begin{abstract}
Autor przedstawia argumenty za utrzymaniem dwustopniowego systemu awansów naukowych: doktoratu i habilitacji. Jego zdaniem w Polsce nastąpiło znaczące obniżenie poziomu naukowego prac doktorskich. Zostało to spowodowane zbyt dużą liczbą jednostek naukowych, które uzyskały prawa do nadawania stopnia doktora, oraz obniżeniem wymagań stawianych kandydatom do tego stopnia. Jego zdaniem należy utrzymać — wywodzący się z tradycji uniwersytetu niemieckiego zreformowanego przez Wilhelma von Humboldta — wymóg habilitacji jako drugiego (wyższego) stopnia naukowego. Jego uzyskanie daje pełne prawa akademickie badaczowi, jednakże procedura nadawania habilitacji musi być zmieniona. Autor opowiada się za przeprowadzaniem habilitacji poza macierzystą jednostką kandydata i opiniowaniem jej przez recenzentów pochodzących też spoza jednostki zatrudniającej i przeprowadzającej przewód habilitacyjny. Zdaniem autora recenzje powinny być prowadzone w trybie peer review i z ostrożnym odnoszeniem się do wskaźników bibliometrycznych — w duchu Deklaracji DORA z San Francisco z 2012 r.
\end{abstract}

\section{The necessity to maintain habilitation in Poland}

The author presents arguments for maintaining a two-degree system of academic qualification: doctorate and habilitation. In his view, the scientific level of doctoral dissertation in Poland has lowered significantly in recent years. This situation results from the fact that too many academic entities have the right to confer doctoral degree and from the fact that the requirements for the candidates are now less demanding. It is the author's opinion, that the requirement for a habilitation thesis, stemming from the tradition of German university reformed by Wilhelm von Humboldt, as the second (higher) academic qualification ought to be maintained. This degree makes the scholar a fully-fledged academic. However, the procedure of obtaining habilitation should be changed. The author advocates conferring the qualification not by the home university of the candidate and appointing reviewers who also do not come from the candidate's home university nor from the university carrying out the procedure of habilitation. The reviews ought to be based on the method of peer review, thus the and bibliometric indicators should be treated with caution - in line with the DORA declaration signed in San Francisco in 2012.

NOWOTWORY Journal of Oncology 2015; 65, 4: 292-297

Słowa kluczowe: doktorat, habilitacja, peer review, DORA

Key words: doctorate, habilitation, peer review, DORA

Polski (ale też europejski i w jakiejś części — światowy, np. Uniwersytet Harvarda) nowoczesny uniwersytet kształtował się pod wpływem reformatorskiej wizji Wilhelma von
Humboldta, który na początku XIX wieku miał — ideowo decydujący - wpływ na powołanie Uniwersytetu Berlińskiego. W tej, jakże trwałej, wizji znalazło się miejsce na sys-

Instytut Psychologii

Uniwersytet im. Adama Mickiewicza w Poznaniu

Prof. Jerzy Brzeziński jest dyrektorem Instytutu Psychologii Uniwersytetu Adama Mickiewicza w Poznaniu, członkiem rzeczywistym Polskiej Akademii Nauk, przewodniczącym Sekcji Nauk Humanistycznych i Społecznych Centralnej Komisji ds. Tytułu Naukowego i Stopni Naukowych, doktorem honoris causa Uniwersytetu Kazimierza Wielkiego I Uniwersytetu Gdańskiego. 
tem awansów naukowych. Polska, odrodzona po 1918 roku w swoich najstarszych uniwersytetach: Krakowa, Lwowa, Wilna i Warszawy oraz tych najmłodszych: Lublina i Poznania nawiązała do tej tradycji. A trzeba pamiętać, że dopiero narzucona po II wojnie światowej sowietyzacja systemu szkolnictwa wyższego doprowadziła do wyrzucenia poza uniwersytecki nawias także wydziałów medycznych i, na szczęcie na kilka lat zaledwie (lata: 1951-1958), zastąpienia europejskiego systemu gradacji awansów naukowych obcym kulturowo systemem rosyjskim z jego dwustopniowym systemem awansowym: „kandydata nauk” (polski doktor) i „doktora nauk" (polski doktor habilitowany). Co ciekawe, tylko dwie polskie uczelnie medyczne zdecydowały się rozstać się z narzuconymi przed dziesiątkami lat (politycznie motywowanymi!) zmianami i powróciły na uniwersyteckie łono. Mam na myśli Akademie Medyczne w Krakowie i w Bydgoszczy. Pierwsza powróciła do swojego Uniwersytetu Jagiellońskiego jako Collegium Medicum. Z kolei druga skorzystała z zaproszenia Uniwersytetu Mikołaja Kopernika i stała się tegoż Collegium Medicum (z siedzibą w Bydgoszczy). Myślę, że obie strony tego akademickiego — i podkreślmy, z ducha europejskiego - porozumienia, przekreślającego skutki nieprzynoszącego akademickiej chluby, oderwania wydziałów medycznych od macierzystych uniwersytetów na tym historycznym połączeniu tylko zyskały. Pozostałe Akademie Medyczne zadowoliły się quasi-rozwiązaniem pod postacią dziwnego tworu — wymyślonego przez polityków — „uniwersytetu przymiotnikowego"; tu: „uniwersytetu medycznego".

\section{Stan kadry naukowej w Polsce i aktualny system awansów naukowych}

Aby przedyskutować problem: „Z habilitacją czy bez habilitacji?", należy wpierw zorientować się w: 1) stanie posiadania, jeśli chodzi o kadry naukowe (a te medyczne w szczególności) oraz 2) celowości dokonania zmian polegających na usunięciu z tego systemu jednego, ale o kapitalnym znaczeniu, elementu.
Na koniec 2012 r. w różnych instytucjach naukowych i w szkolnictwie wyższym było zatrudnionych 76069 pracowników naukowych i nauczycieli akademickich. Kadra naukowa w stopniu doktora to ogółem 51145 osób. Z kolei kadra naukowa w stopniu doktora habilitowanego liczyła 14272 osób, zaś kadra naukowa z tytułem profesora, to 10652 pracowników. W tabeli I pokazano strukturę kadry naukowej według reprezentowanego przez nią obszaru nauk. W szczególności chciałbym zwrócić uwagę na nasycenie szkolnictwa wyższego (z obszaru nauk medycznych, nauk o zdrowiu i nauk o kulturze fizycznej) kadrą ze stopniem doktora. Wg tego samego źródła w publicznym szkolnictwie medycznym i AWF znalazło zatrudnienie 10928 osób, co stanowi 87,1 \% całej kadry naukowej z tego obszaru nauk (doktorów, doktorów habilitowanych i profesorów). Mamy zatem - w stosunku do liczby uczelni i instytutów badawczych sprofilowanych medycznie — spore nasycenie kadrami ze stopniem naukowym w interesującym nas obszarze. Pytanie, raczej retoryczne, czy wszyscy oni powinni przejść do wyższej (wymagającej i relatywnie wyższych kwalifikacji naukowych i znaczących osiągnięć naukowych — dziś muszą one być odnoszone do poziomu nauki światowej (poziom krajowy jest już, w jakimś sensie, passé; jest on akceptowalny jedynie w odniesieniu do kategorii „doktora") — kategorii pracowników naukowych czy naukowo-dydaktycznych. Oczywiście, że nie. Rozkład predyspozycji do pracy badawczej przyjmuje - jak wiele innych cech w przyrodzie - kształt rozkładu Gaussa (rozkład normalny).

Pytanie o habilitację jest tak naprawdę pytaniem o wyznaczenie progu awansowego (w modelu krzywej Gaussa idzie o wskazanie punktu odcięcia) w instytucjach zatrudniających młodych badaczy (nauczycieli akademickich). Najkrócej rzecz ujmując, idzie o znalezienie optymalnego kryterium „usamodzielnienia” pracownika ze stopniem doktora. Owo usamodzielnienie w prawnie regulowanych w Polsce ramach oznacza nie tak mało. Po pierwsze, oznacza możliwość sprawowania opieki naukowej (promotorstwo) nad lekarzami/inżynierami/magistrami, którzy aspirują do osiągnięcia

Tabela I. Kadra naukowa wg reprezentowanego przez nią obszaru nauk

\begin{tabular}{|c|c|c|c|c|c|c|}
\hline \multirow[t]{2}{*}{ Obszar nauk } & \multicolumn{2}{|c|}{ Doktor } & \multicolumn{2}{|c|}{ Doktor habilitowany } & \multicolumn{2}{|c|}{ Profesor } \\
\hline & Liczba & $\%$ & Liczba & $\%$ & Liczba & $\%$ \\
\hline Humanistycznych & 10643 & 66,0 & 3645 & 23,0 & 1883 & 12,0 \\
\hline Społecznych & 8777 & 71,0 & 2268 & 18,0 & 1325 & 11,0 \\
\hline Ścisłych & 4499 & 64,0 & 1208 & 17,0 & 1332 & 19,0 \\
\hline Przyrodniczych & 3123 & 65,0 & 978 & 20,0 & 726 & 15,0 \\
\hline Technicznych & 10682 & 72,0 & 2402 & 16,0 & 1846,0 & 12,0 \\
\hline Rolniczych, leśnych i weterynaryjnych & 3267 & 62,0 & 1000 & 19,0 & 1007 & 19,0 \\
\hline Medycznych, o zdrowiu, o kulturze fizycznej & 8869 & 71,0 & 1953 & 16,0 & 1730 & 14,0 \\
\hline Sztuki & 1285 & 44,0 & 818 & 28,0 & 803 & 28,0 \\
\hline
\end{tabular}

Źródło: dane ujęte w tabeli I pochodzą z: Nauka w Polsce 2013, Edycja 1; por. https://www.nauka.gov.pl/g2/oryginal/2013_08/010df9372ca1a016e6e9bf7746817b38.pdf Pozyskano 26-06-2015 
stopnia naukowego doktora. Po drugie, oznacza możliwość występowania, w charakterze recenzenta w przewodach doktorskich i habilitacyjnych (chyba że te drugie zniesiemy). Po trzecie, oznacza możliwość wchodzenia do tzw. „minimum kadrowego"jednostki ubiegającej się o możliwość nadawania stopnia doktora, doktora habilitowanego oraz popierania wniosku o nadanie przez Prezydenta RP tytułu naukowego profesora. Po trzecie, oznacza możliwość wchodzenia do tzw. „minimum kadrowego" jednostki ubiegającej się o możliwość poprowadzenia kierunku studiów (pierwszego i drugiego stopnia — odpowiednio kończących się uzyskaniem przez absolwenta tytułu zawodowego licencjata i magistra/lekarza/inżyniera). Po czwarte, oznacza inne możliwości obejmowania różnych stanowisk w instytucjach, których statuty zastrzegły, iż osoba ubiegająca się o dane stanowisko musi być tzw.,,samodzielnym” pracownikiem naukowym, co w praktyce oznacza posiadanie habilitacji, a niekoniecznie tytułu naukowego profesora - np. w warunkach konkursowych na stanowisko dyrektora instytutu PAN-owskiego może być wymienione kryterium posiadania habilitacji. To bardzo znaczące uprawnienia. Zatem zasadne jest pytanie: Komu można je przydzielić, aby osoba z nich korzystająca nas nie zawiodła? Prosta odpowiedź, że „właściwej” — pod względem kwalifikacji naukowych — osobie nas raczej nie zadowala. Bo co to znaczy, że dana osoba jest „właściwa”? I kto ma o tym decydować? Jeśli chodzi o kwalifikacje osoby ubiegającej się o nadanie jej stopnia naukowego doktora, to środowisko od dziesiątków lat jest raczej zgodne - powinna o tym decydować rada naukowa czy rada wydziału, której kompetencje w tym zakresie ocenia Centralna Komisja. Można jednak zastanawiać się, czy kryteria stosowane przez Centralną Komisję nie są nazbyt liberalne. Moim zdaniem: nie tylko są zbyt łagodne, ale też zbyt dużo jednostek uczelnianych i instytutowych uzyskało takie prawo. W konsekwencji zbyt łatwo, znacznie łatwiej, aniżeli na początku lat 90. ubiegłego wieku można dziś uzyskać stopień doktora. Nastąpiła wstydliwa inflacja tego stopnia naukowego, dziś nie jest on wyróżnikiem szczególnie wysokich kwalifikacji naukowych. I to jest główny powód mojego sprzeciwu wobec pojawiających się zakusów (a z poziomu ministerialnego tę swoistą puszkę Pandory otworzyła była minister ds. nauki prof. Barbara Kudrycka, która bardzo starała się — na szczęście nieskutecznie —o to, aby znieść habilitację) „uproszczenia" systemu awansu naukowego. Ale o tym niżej.

Wróćmy jednak do pytania o możliwości uzyskiwania dwóch stopni naukowych w interesującym nas obszarze naukowym. Wg informacji zaczerpniętej ze strony WWW Centralnej Komisji do Spraw Stopni i Tytułów (stan: marzec 2015) dowiadujemy się, że uprawnienia do nadawania stopni naukowych doktora i doktora habilitowanego w obszarze nauk medycznych i nauk o zdrowiu oraz nauk o kulturze fizycznej w dziedzinie: 1) nauk medycznych (biologia medyczna, medycyna, stomatologia), 2) nauk farmaceutycznych, 3) nauk o zdrowiu i 4) nauk o kulturze fizycznej posiadają:

— Uczelnie medyczne: 77 jednostek (dr), 57 jednostek (hab.);

- AWF: 13 jednostek (dr), 7 jednostek (hab.);

— Instytuty i inne jednostki: 21 jednostek (dr), 9 jednostek (hab.).

Jestem przekonany, że zbyt dużo jednostek otrzymało takie uprawnienia. Przez lata nic (dosłownie) nie zrobiono, aby - stopniowo - podnosić wymagania awansowe. Działania muszą mieć charakter kompleksowy i powinny obejmować nie tylko to, co może wnieść kandydat (jego osiągnięcia: przede wszystkim znaczące publikacje), ale także to, jakie wymagania naukowe stawia kandydatom jednostka prowadząca dany przewód awansowy. Podejmowanie działań naprawczych, wyrwanych z całego kontekstu uwarunkowań, działań o charakterze propagandowym czy nawet dyscyplinujących — jest szkodliwe, i nie będzie przynosiło oczekiwanych rezultatów. Te i tak będą dopiero widoczne po iluś latach i raczej w dalszej, aniżeli krótszej perspektywie czasowej. Ale żeby uzyskać „jutro" spodziewany wynik,"dziś" musimy podjąć określone działania naprawcze. A zatem wróćmy do naszej tytułowej kwestii.

Zanim jednak to zrobimy, zauważmy wpierw, jak niebezpieczne i zgubne dla poziomu awansów naukowych może być gwałtowne i nieprzemyślane „majstrowanie” przy ustawach i rozporządzeniach dotyczących nauki. Pokazują to dane dotyczące liczby wniosków o poparcie uchwał rad jednostek w przedmiocie nadania przez Prezydenta RP tytułu profesora. Ów nawał wniosków spowodowany był istnym podniesieniem wymagań naukowych stawianych tym wnioskom. Duża część kandydatów do tytułu naukowego chciała, mówiąc kolokwialnie, załapać się na bardziej liberalne warunki starej ustawy. Nowa ustawa, która weszła w życie 1 października 2011 r., przewidywała bowiem przez okres dwóch lat możliwość poprowadzenia wniosków awansowych jeszcze w trybie starej ustawy (art. 33).W efekcie niespotykanej dotychczas wzmożonej aktywności „naukowej” wielu uczonych Centralna Komisja została - dosłownie — zamurowana wnioskami, z którymi do dnia dzisiejszego jeszcze się nie uporała. Utworzyła się gigantyczna kolejka spraw do rozstrzygnięcia na kolejnych, jednodniowych (przez 10 miesięcy w roku) posiedzeniach sekcji CK. A wystarczyło posłuchać głosów środowiska...

Poniższe zestawienie ilustruje skalę problemu [podaję za:Tajduś A. (2014). Działalność Centralnej Komisji do Spraw Stopni i Tytułów w okresie 15.02.2013-30.09.2014]:

- 2011 - liczba zgłoszonych wniosków: 856;

- 2012 - liczba zgłoszonych wniosków: 760;

— 2013 - liczba zgłoszonych wniosków: 1818 (30-09 wygasał art. 33);

- 2014 (do września) - liczba zgłoszonych wniosków: 1500. 


\section{Dwa stanowiska w kwestii awansu podoktorskiego}

Od jakiegoś czasu - z większym lub mniejszym oddźwiękiem w mediach — pojawia się postulat zlikwidowania habilitacji jako swoistego anachronizmu i nienadążania za nowoczesną Europą (o USA nie wspominając). W jej miejsce proponuje się... No i tu pojawia się zasadnicze pytanie: Co się proponuje?

Propozycja, której nie aprobuję, sprowadza się do utrzymania tylko jednego stopnia naukowego doktora (ale nie mówi się nic na temat chociażby zwiększenia wymagań stawianych samym kandydatom do tego stopnia, jak i radom jednostek, które uzyskują stosowne uprawnienia) oraz tytułu naukowego profesora. Gdyby zlikwidowano stopień naukowy doktora habilitowanego, to byłby on nadawany osobom ze stopniem doktora. Ułatwiono by zatem dostęp do tego tytułu. Dziś trzeba pokonać przeszkodę pod postacią habilitacji. W Polsce tytuł profesora - co jest jednak jakąś osobliwością — nadaje Prezydent RP, po uprzedniej akceptacji wniosku danej rady przez Centralną Komisję. Sprawę komplikuje wprowadzenie na początku lat 90. ubiegłego wieku dwóch stanowisk profesorskich: profesora zwyczajnego (dostępnego osobom posiadającym tytuł naukowy profesora) oraz profesora nadzwyczajnego (dostępnego osobom posiadającym habilitację). Oba stanowiska są obsadzane przez władze uczelni w drodze konkursu, którego warunki określa autonomicznie dana uczelnia. Teoretycznie przynajmniej liczba tych stanowisk nie jest limitowana (chyba co najwyżej przez kondycję finansową uczelni). Dziś w „peryferyjnych" uczelniach stanowisko profesora zwyczajnego uzyskuje się niemalże automatycznie po uzyskaniu tytułu profesora. W uczelniach o wysokiej randze naukowej na to stanowisko trzeba poczekać i wykazać się jakąś nową aktywnością naukową.

Wydaje mi się, że nieuchronną konsekwencją likwidacji habilitacji na rzecz - w drodze konkursu obsadzanego - wyższego stanowiska (chyba jednak stanowiska?) naukowego musiałaby być likwidacja tytułu naukowego profesora. Jeżeli nie, to krytyczne stanowisko przeciwników habilitacji jako zbędnego, biurokratycznego utrudnienia w procesie rozwoju naukowego badacza ulega znacznemu stępieniu. Myślę — jeżeli przez moment zapomnę o mojej dezaprobacie dla likwidacji habilitacji — że po jedynym progu naukowym (doktoracie) w karierze naukowej badacza pojawić by się mogły dwa progi awansu zawodowego związane z miejscem zatrudnienia badacza, które też byłyby obsadzane w trybie konkursu uczelnianego o nieograniczonym de facto zasięgu. Zwolennicy likwidacji drugiego stopnia naukowego mówią — chociaż gdy dochodzi do uściślenia stanowiska, to trudno o konkretne rozwiązania - o konieczności uszczelnienia procedury doktorskiej i o wyśrubowaniu kryteriów konkursowych wedle których nadawano by wyższe uprawnienia naukowo-zawodowe.
Ja jednak jednego nie mogę zrozumieć: jeżeli mamy wprowadzać — lokalnie uściślane — kryteria „usamodzielniania” doktorów (bo chyba jednak nie wszyscy doktorzy mieliby, niejako z automatu, uzyskiwać różne uprawnienia: promotorstwa, recenzowania itp.) i przydzielania im stanowisk profesorskich, to w czym ten nowy system miałby być lepszy od dotychczasowego? Bo dziś, jeżeli ktoś ma dobry dorobek naukowy (co należy czytać, że systematycznie publikuje $w$ dobrych czasopismach naukowych z listy $J C R$, jest aktywny na dobrych konferencjach naukowych, pozyskuje granty), to habilitowanie się z jednotematycznego cyklu publikacji jest dość przyjazne. Jedyne co musi zrobić, to napisać autoreferat i skompletować publikacje. Po pewnym czasie dostanie zaświadczenie od przewodniczącego danej rady, iż właśnie nadano mu stopień doktora habilitowanego. Co w tym trudnego? Jakie to kłody rzuca się pod nogi młodemu, zdolnemu badaczowi? Czy czasem nie przesadza się? Jeżeli jednak mamy do czynienia z miernotą naukową, to nie przejdzie ona ani przez sito tradycyjnej habilitacji, ani przez sito jeszcze ambitniej pomyślanej komisji konkursowej. Chyba że zgadzamy się na takie oto rozwiązanie. Dopuśćmy w kiepskich uczelniach do stanowisk profesorskich słabszych naukowo badaczy, niech i tam mają dużo profesorów i niech i oni wypuszczają w świat jeszcze gorszych doktorów. Stwórzmy zatem enklawy "naukowej doskonałości”, salony, na które tylko nielicznym będzie wolno wejść. Jasne, że chcielibyśmy mieć w Polsce nasze „harvardy”. Każdy by chciał. Jest tylko jeden problem: jak zapewnić przez dziesiątki lat wysoki poziom finansowania szkolnictwa wyższego w tak biednym kraju, jakim jest Polska? Z pustego i Salomon...

W czym lepszy miałby być system bez habilitacji? Dziś stanowi on obronę przed beztrosko i bez umiaru nadawanymi kiepskimi doktoratami. Jest to obrona — może nie do końca skuteczna, ale zawsze jakaś! - przed dalszym awansem naukowym osób, które swój poziom kompetencji badawczych wyczerpały jeszcze przed podjęciem tematu pracy doktorskiej (tu naturalnie rodzi się pytanie: a co robił promotor?). Zniesienie na początku ubiegłego wieku kontroli nad habilitacjami sprawowanej przez Centralną Komisję istotnie osłabiło ten mur obronny. Kiedyś świadomość kontroli poziomu nadawanej przez radę jednostki habilitacji zniechęcała i marnego naukowo kandydata, i samą radę, która i nie chciała się kompromitować, i obawiała się zabrania jej uprawnień. Dziś mamy i więcej habilitacji, i są one na niższym poziomie - ale są. Wystarczy nad nimi popracować. Habilitacja jest czymś w rodzaju „Zamku Wysokiego" do którego przenosili się obrońcy średniowiecznego kompleksu obronnego, gdy padał „Zamek Dolny”. Myślę, że doktoraty —zwłaszcza traktowane jako zwieńczenie kształcenia $\mathrm{III}^{0} \mathrm{~W}$ zbiurokratyzowanym tzw. Systemie Bolońskim - są już nie do odzyskania. Co nam pozostało? Obrona Zamku Wysokiego - habilitacji. 
I jeszcze jedno: ja bym się nie odwracał od tradycji Humboldtowskiej, która kształtowała nasz europejski uniwersytet. I co też warto odnotować - w niektórych krajach przywraca się ją. Tak jest np. we Włoszech.

\section{Co należy zmienić w procedurze habilitacyjnej?}

Moim zdaniem, wymagane są trojakiego rodzaju zmiany. Pierwsza dotyczy uprawnień do nadawania stopnia doktora habilitowanego, przyznawanych przez Centralną Komisję jednostkom: wydziałom i instytutom. Druga dotyczy wymagań stawianych kandydatom. Trzecia dotyczy recenzji wytwarzanych $w$ trakcie postępowania kwalifikacyjnego. Zatem po kolei.

\section{Kadra naukowa wymagana dla uzyskania uprawnień habilitacyjnych}

Przez ostatnie 25 lat nie zmieniono kryteriów kadrowych formułowanych wobec jednostek (wydziałów i instytutów) ubiegających się o możliwość prowadzenia przewodów habilitacyjnych, i w konsekwencji ich przyznania oraz opiniowania wniosków o nadanie danemu kandydatowi przez Prezydenta RP tytułu naukowego profesora. Mimo iż przez te lata znacząco uległa zwiększeniu kadra samodzielnych pracowników naukowych, to nadal obowiązują te same kryteria. Były one wówczas dość trudne do spełnienia, zwłaszcza przez niewielkie jednostki. Przypomnijmy, że aby dana jednostka mogła prowadzić przewody habilitacyjne, to musiała (i jedynie co się w tym zakresie zmieniło, to wprowadzony później wymóg, iżby było to zatrudnienie w jednostce jako podstawowym miejscu pracy osoby zaliczanej do tzw. minimum kadrowego) zatrudniać w pełnym wymiarze czasu pracy 12 osób ze stopniem doktora habilitowanego $w$ danej dziedzinie naukowej, a w tym 5 osób powinno reprezentować daną dyscyplinę naukową; ponadto wśród tych osób powinno być 6 profesorów danej dziedziny naukowej; po ostatniej nowelizacji ustawy liczbę profesorów ograniczono do 3! Tak więc jakiś wydział uczelni medycznej, powiedzmy lekarski, ubiegający się o uprawnienia habilitacyjne w dziedzinie „nauk medycznych” i dyscyplinie: „medycyna” powinien zatrudniać 12 doktorów habilitowanych w dziedzinie „nauk medycznych", z których co najmniej 5 reprezentuje dyscyplinę naukową „medycyna"; w tej grupie powinno znaleźć się 3 profesorów w dziedzinie „nauk medycznych". Oczywiście dana osoba może wchodzić do minimum kadrowego tylko jednej jednostki i może być w nim uwzględniona po minimum rocznym zatrudnieniu $w$ danej jednostce. Przyznają PT Czytelnicy, że przez lata nastąpiła znacząca inflacja tych kryteriów. To tak, jakby złożyć do banku 25 lat temu 100 zł i się tą lokatą bankową nie interesować. Prawda, że to absurdalne? Chyba nie ma w Polsce takiego wydziału lekarskiego, który nie spełniałby owych kryteriów ilościowych? Przecież przez te lata znacząco wzrosła liczba profesorów i doktorów habilitowanych. Powiedzą Państwo, że uprawnienia nie są przyznawane automatycznie, że poziom naukowy jednostki jest opiniowany przez rzeczoznawców Rady Głównej, i przede wszystkim przez Centralną Komisję. Tak jest, ale i tu kryteria się złagodziły, i powinny być istotnie zaostrzone. Nie idzie bowiem o to, aby wszyscy mogli przyznawać wszystko. Uprawnienia do nadawania najwyższego stopnia naukowego powinny być przyznawane tylko niezbyt licznym jednostkom, które faktycznie reprezentują najwyższy poziom naukowy. Na początek w zespole (prof. J. Brzeziński, UAM; prof. M. Pałys, rektor UW i prof. B. Marciniak, rektor UAM) powołanym przez Konferencję Rektorów Uniwersytetów Polski (KRUP) powstała, na zamówienie minister prof. L. Kolarskiej-Bobińskiej, ekspertyza dotycząca nowych standardów habilitacyjnych. Według niej nowe progi kadrowe powinny wyglądać następująco: 18 osób z habilitacją w danej dziedzinie naukowej, w tym 9 profesorów tej dziedziny i 8 doktorów habilitowanych reprezentujących daną dyscyplinę naukową.

Moim zdaniem, należy też zaostrzyć kryteria wobec członków rady jednostki, a zwłaszcza tej jej części, która tworzy minimum kadrowe. Najlepszym wskaźnikiem pozycji naukowej są publikacje i dotychczasowe doświadczenie promotorskie i recenzenckie. Jeśli chodzi o publikacje, to ocenie - ale typu peer review! — powinna podlegać tylko ich ograniczona do najlepszych (przede wszystkim w obiegu międzynarodowym i z przewagą tych, w których dany badacz jest tzw. first author czy corresponding author), wskazana przez niego samego liczba (powiedzmy: nie więcej niż 10). Osobiście nie mógłbym przyznać uprawnień habilitacyjnych jednostce, która zatrudnia osoby o nikłym (o braku nie mówmy!) doświadczeniu recenzenckim i promotorskim. Uważam też, że dana osoba mogłaby być zaliczana do minimum kadrowego dopiero po upływie pewnego okresu czasu od uzyskania przez nią habilitacji (moim zdaniem — około 5 lat).

\section{Wymagania stawiane kandydatom}

Mój pogląd na ocenę dokonań naukowych kandydatów do habilitacji jest dość klarowny i prosty (przeciwko biurokratyzowaniu procedury). Od kandydata należałoby wymagać aktywności w dwóch sferach. Pierwsza i najważniejsza, to publikacje — przede wszystkim artykuły naukowe zamieszczone w dwóch bazach: (1) JCR — Thomson Reuters (http://wokinfo.com/products_tools/analytical/jcr/ ) i SClmago (Scopus) — Elsevier (por. http://www.scimagojr.com/). Ograniczyłbym też liczbę artykułów zgłaszanych do oceny. Niech to sam kandydat wskaże te, jego zdaniem, najlepsze. I niech ich będzie nie więcej, aniżeli, powiedzmy, 5-10. Z kolei recenzent $w$ trybie peer review oceni każdy z nich. Aktywność konferencyjna (zwłaszcza postery, które są dość często wykorzystywane w celach turystyki konferencyjnej) jest tylko o tyle istotna, by wygłoszony referat przełożył się 
na opublikowany w dobrym czasopiśmie artykuł. Zatem oceniałbym ją dopiero na drugim planie. I w tym przypadku ważna jest kolejność autorów w przypadku artykułów (coraz częściej staje się czymś powszechnym) wieloautorskich oraz określenie rzeczywistego wkładu w ich powstanie (nie tylko określony procentowo i przez współautorów, a nie przez samego kandydata do stopnia naukowego). Ten wkład powinien być skomentowany przez recenzenta.

\section{Wymagania stawiane recenzentom i radom jednostek}

Te chciałbym skomentować w świetle niedawno opublikowanej Deklaracji DORA z San Francisco: San Francisco Declaration on Research Assessment. Putting science into the assessment of research (por. http://www.ascb.org/dora-old/files/SFDeclarationFINAL.pdf ). Ta powstała w grudniu 2012 roku w środowisku biologów komórki deklaracja zyskała dość powszechne poparcie w świecie. W Polsce podpisała ją Fundacja na rzecz Nauki Polskiej (kierowana przez prof. Macieja Żylicza — por. Oświadczenie władz Fundacji na rzecz Nauki Polskiej. http://www.fnp.org.pl/assets/O\%C5\%9Bwiadczenie-Rady-i-Zarz\%C4\%85du-FNP.pdf). Podzielam stanowisko DORA w kwestii mechanicznego stosowania różnych wskaźników bibliometrycznych i naukometrycznych do oceny dorobku pojedynczych badaczy, a zwłaszcza IF: Do not use journal-based metrics, such as Journal Impact Factors, as a surrogate measure of the quality of individual research articles, to assess an individual scientist's contributions, or in hiring, promotion, or funding decisions. Jestem, idąc dalej, przeciwnikiem (prawnie nie do zaakceptowania) podejmowania uchwał przez rady wydziałów czy nawet senaty uczelni (zwłaszcza medycznych), aby do wszczęcia procedury habilitacyjnej (też profesorskiej) dopuszczać tylko te osoby, których wartości wskaźników bibliometrycznych i naukometrycznych: sum IF czy zsumowana liczba cytowań publikacji kandydata przekraczają pewną, arbitralnie wyznaczoną wartość progową. Taka praktyka jedynie sprzyja rozpowszechnianiu patologicznego zjawiska tworzenia "spółek" autorskich w celu zwiększenia wartości owych wskaźników. I zdecydowanie jestem przeciwny takim karykaturalnym opisom dorobku naukowego jak ten „wzięty z życia” (aczkolwiek odpersonalizowany): „Sumaryczny impact factor moich publikacji naukowych według listy Journal Citation Reports wynosi xxx; sumaryczna liczba punktów MNiSzW/KBN jest równa xxx, a IC - xxx. Liczba cytowań moich prac według bazy Web of Science (bez autocytowań) jest równa xx". Nie należy przymuszać kandydatów, aby dokonywali takiego zredukowanego opisu swojego dorobku naukowego.

Wyżej napisałem, przeciwko czemu protestuję, a za czym się opowiadam. W skrócie — opowiadam się za:

- poprowadzeniem przewodów habilitacyjnych przed obcą radą jednostki (poza miejscem zatrudnienia kandydata);

- powoływaniem wyłącznie recenzentów spoza miejsca zatrudnienia kandydata i spoza rady prowadzącej przewód;

- eliminacją zjawiska "rozcieńczenia dorobku" - oceniane powinny być tylko najważniejsze, wskazane przez kandydata, publikacje;

- ostrożnym odwoływaniem się do wskaźników bibliometrycznych — ze wskazaniem na indeks Hirscha;

- stosowaniem - przede wszystkim! - oceny poprowadzonej w trybie peer review.

Zatem - dochodząc do konkluzji — jestem za utrzymaniem zreformowanej habilitacji.

Prof. dr hab. Jerzy Marian Brzeziński

czł. rzecz. PAN; dyrektor Instytutu Psychologii UAM

ul. Szamarzewskiego 89, 60-568 Poznań

e-mail:brzezuam@amu.edu.pl

Otrzymano i przyjęto do druku: 28 czerwca 2015 r.

Na podstawie wystąpienia podczas III Konferencji Naukowej czasopisma Nowotwory „Debaty onkologiczne" 10-11 kwietnia 2015 roku 